\title{
Penerapan Model Kooperatif Tipe Jigsaw Untuk Meningkatkan Kualitas Pembelajaran dan Keaktifan Berbicara Siswa Kelas VII A SMP N 14 Kota Jambi
}

\author{
Germilasmawani. S \\ SMP N 14 Kota Jambi \\ Email: germilasmawani@ymail.com
}

\begin{abstract}
Speaking learning activity is still low in SMP Negeri 14 Kota Jambi.To overcome this problem researcher chooses Jigsaw cooperative learning model as an alternative to enable learners to speak. This study aims to know the successful of implementation cooperative learning model Jigsaw to improve the quality of the processes and outcomes of learning speaking participationof VIIA grade students SMP N 14 Jambi. This research is a classroom action research. The subjects were 32 students of class VIIA SMPN 14 Jambi. The study was conducted three cycles each cycle begins with the planning, implementation, analysis and reflection. The instruments used were observation sheet, field notes, closed questionnaire, and the performance test. Data analysis techniques of quality of process implementation of Jigsaw are done with data reduction, data display, verification and conclusion drawing, while data of learning outcomes qualitywere analyzed by using average formula. The results of the study were classified into two, namely the quality of the learning process and the quality of students' speaking participation learning outcomes. The quality of the learning process in the first cycle and the second cycle is still low. It can be seen from the students' low participationin speaking. But in the third cycle the quality of the learning process has been successful. From 32 students, spontaneous expression in first cycle wasonly 8, in second cyclewas 16, in third cycle was 24; expressing their opinions as assigned the first cycle was 10, the second cycle was 19, the third cycle 26; responding to the opinion of friends in first cycle was 8 , in second cycle was 16, in third cycle 24; asking questions first cycle 9, the second cycle 18, the third cycle 25; answering friends' / teacher's questions in first cycle was 10, the second cycle 18, the third cycle 25. Based on these results it can be concluded that the implementation of cooperative learning model Jigsaw can improve process quality and students' speaking participation learning outcomes. Thus researcher suggests to the teachers to use Jigsaw cooperative model in their teaching learning process. But a classroom action research through Jigsaw model still need to be followed up with more innovative development.
\end{abstract}

Keywords: jigsaw cooperative learning models, learning process quality, students' speaking participation

\section{PENDAHULUAN}

Hakikat belajar bahasa yaitu belajar berkomunikasi baik lisan maupun tertulis sesuai dengan situasi dan konteksnya. Pembelajaran berbicara juga sebagai upaya melatih siswa berani mengemukakan pendapat, berani menanggapi pendapat teman, berani bertanya dan menjawab pertanyaan teman/guru. Mereka diharapkan dapat tumbuh dan berkembang menjadi individu yang cerdas, terampil mengungkapkan ide-ide, mengemukakan pendapat, gagasan, pikiran, perasaan dan tanggapan yang disampaikan kepada orang lain.

Dalam pembelajaran Bahasa Indonesia, aspek berbicara adalah bagian dari sistem pembelajaran bahasa yang mengarah pada aspek keterampilan dan bukan hanya pemahaman kognitif. Oleh karena itu pembelajaran berbicara diupayakan dapat merespon siswa secara positif agar mampu berkomunikasi menggunakan bahasa Indonesia dengan tepat untuk mengemukakan pendapat, ide-ide, pikiran-pikiran, perasaannya dan dapat memunculkan gagasangagasan yang logis sesuai dengan konteksnya. Dengan demikian guru mempunyai peran penting dalam meningkatkan keaktifan berbicara siswa. Guru harus mampu membuat bahan ajar dan metode pembelajaran yang sesuai agar siswa berperan aktif berbicara dalam kegiatan pembelajaran. Guru harus kreatif memilih model pembelajaran yang sesuai untuk memotivasi siswa agar berani mengemukakan pandapat/idenya dalam pembelajaran.

Kenyataan yang terjadi saat ini bahwa pembelajaran berbicara di SMP Negeri 14 Kota Jambi masih rendah. Hal ini dapat ditandai dari kemampuan siswa saat mengemukakan pendapat, menanggapi pendapat teman, mengajukan pertanyaan, dan menjawab pertanyaan teman/guru dalam proses pembelajaran. Dalam kegiatan pembelajaran sehari-hari bila siswa diminta mengemukakan pendapatnya atau menanggapi pendapat temannya, mengajukan pertanyaan atau menjawab pertanyaan teman/guru atau pun menceritakan pengalamannya hanya sebagian kecil siswa dapat menyampaikannya cara penyampaiannya pun tidak efektif.

Peneliti juga melihat dalam pelaksanaan proses pembelajaran berbicara di kelas masih didomonasi oleh guru. Guru lebih dominan ceramah dalam kegiatan pembelajaran berbicara sehingga siswa menjadi pasif. Kesulitan siswa berbicara tampak ketika siswa diminta mengemukakan pendapatnya, menanggapi pendapat temannya, mengajukan pertanyaan, dan menjawab pertanyaan teman/guru saat proses pembelajaran berlangsung. Diduga masalah tersebut belum dapat diatasi karena model pembelajaran yang digunakan oleh guru kurang tepat untuk proses pembelajaran berbicara di kelas.

Selama ini proses pembelajaran berbicara yang dilakukan oleh guru untuk mengaktifkan siswa berbicara hanya sebatas tanya-jawab. Selain masalah yang telah disebutkan, berdasarkan pengamatan di lapangan ada beberapa penyebab siswa mengalami kesulitan berbicara terutama mengemukakan pendapatnya, menanggapi pendapat temannya, mengajukan pertanyaan, dan menjawab pertanyaan teman/guru dalam pembelajaran, penyebab tersebut di antaranya :

1. Siswa tidak percaya diri mengemukakan pendapatnya karena takut salah dan malu jika ditertawai temannya.

2. Jika guru menunjuk langsung salah satu siswa, misalnya untuk menjawab pertanyaan temannya, 
siswa tersebut tampak kaku dan kalimat yang disampaikannya tidak efektif.

Hal ini juga diketahui, sebelum penerapan model pembelajaran kooperatif tipe Jigsaw dari 32 siswa dalam satu kelas hanya satu siswa yang berani berbicara mengemukakan pendapatnya itu pun singkat saja, empat siswa terlebih dahulu menulis pendapatnya lalu dibacakan, sedangkan duapuluh tujuh siswa lainnya hanya diam. Data awal juga ditemukan dari nilai laporan hasil belajar Bahasa Indonesia di kelas VII SMP Negeri 14 Kota Jambi tiga tahun terakhir menunjukkan bahwa nilai rata-rata keterampilan berbicara lebih rendah dari nilai rata-rata keterampilan mendengarkan, membaca, dan menulis. Hal tersebut dapat dilihat pada tabel berikut :

Tabel 1. Rata-Rata Nilai Keterampilan Berbahasa Siswa Kelas VII A SMP N 14 Kota Jambi Tiga Tahun Terakhir

\begin{tabular}{|c|c|c|c|c|c|}
\hline Tahun & \multicolumn{4}{|c|}{ Rata-Rata Nilai Keterampilan Berbahasa } & \multirow{2}{*}{ KKM } \\
\hline Pembelajaran & mendengarkan & membaca & menulis & berbicara & \\
\hline $2012 / 2013$ & 75,80 & 76,68 & 76,52 & 60,32 & 74 \\
\hline $2013 / 2014$ & 76,53 & 77,54 & 76,70 & 62,15 & 75 \\
\hline $2014 / 2015$ & 77,55 & 77,65 & 77,45 & 62,25 & 76 \\
\hline
\end{tabular}

Sumber : Nilai Laporan Hasil Belajar (LHB) mata pelajaran bahasa Indonesia Kelas VII A SMP N 14 Kota Jambi tiga tahun terakhir.

Berdasarkan tabel 1 tersebut dapat dilihat bahwa Kriteria Ketuntasan Minimal (KKM) aspek keterampilan berbicara siswa selama tiga tahun terahir tidak tercapai sesuai dengan yang telah ditetapkan. Sedangkan aspek keterampilan mendengarkan, membaca, dan menulis telah melampaui Kriteria Ketuntasan Minimal (KKM). Sesuai hal tersebut dapat disimpulkan bahwa aspek keterampilan berbicara siswa masih rendah.

Rendahnya kemampuan berbicara tersebut juga diduga berkaitan dengan proses pembelajaran yang dilakukan oleh guru kurang tepat. Proses pembelajaran yang dilakukan oleh guru Bahasa Indonesia di SMP Negeri 14 Kota Jambi masih memiliki kelemahan. Di antaranya guru kurang melibatkan siswa dalam proses pembelajaran berbicara untuk pengembangan pengetahuan dan pengalaman mereka.

Selain data awal, hasil yang diperoleh dari angket adalah dari 32 siswa 25 (78,13\%) menyatakan tidak mau berbicara karena takut salah, $4(12,5 \%)$ menyatakan takut diejek teman jika penyampaian pendapatnaya salah, dan 3 (9,37\% menyatakan malu. Keadaan seperti ini tidak bisa dibiarkan karena dikhawatirkan ke depannya siswa tidak mampu berbicara khususnya mengemukakan pendapatnya, menanggapi pendapat orang lain, mengajukan pertanyaan, dan menjawab pertanyaan orang lain dalam forum di masa yang akan datang. Untuk mengatasi masalah tersebut peneliti memilih model pembelajaran kooperatif tipe Jigsaw sebagai alternatif mengaktifkan siswa berbicara, membiasakan mereka berkomunikasi dengan temannya dan dapat bekerja sama dalam mengerjakan tugas yang diberikan oleh guru sehingga mereka mampu mengemukakan pendapat, memberikan tanggapan, mengajukan pertanyaan, dan menjawab pertanyaan temannya/guru.

Peneliti memilih model pembelajaran kooperatif tipe Jigsaw karena memiliki keunggulan, yaitu siswa dapat aktif berbicara karena model pembelajaran tipe Jigsaw tersebut mengharapkan siswa mampu bertanggung jawab terhadap tugasnya. Untuk mengetahui keberhasilan penerapan model pembelajaran kooperatif tipe Jigsaw ini peneliti mengadakan Penelitian Tindakan Kelas di kelas VIIA. Alasan pemilihan masalah penelitian ini antara lain, (1)
Selama ini belum pernah dilakukan penelitian tindakan kelas untuk meningkatkan kualitas pembelajaran keterampilan berbicara di SMP N 14 Kota Jambi. (2) Model pembelajaran kooperatif tipe Jigsaw memiliki keunggulan untuk meningkatkan keterampilan berbicara. (3) Dipilih model kooperatif tipe Jigsaw ini karena model pembelajaran ini dipandang dapat membentuk kesadaran siswa akan pentingnya belajar dan terlibat dalam aktivitas kelompok. (4) Siswa dapat belajar dan membimbing temannya menjadi tutor sebaya bagi teman yang lain. (5) Model kooperatif tipe Jigsaw dapat menjadikan siswa pemalu menjadi berani berbicara dan siswa yang biasanya kurang aktif dalam belajar akan termotivasi menjadi aktif dalam kelompoknya.

\section{Kajian Pustaka \\ Penelitian yang Relevan}

Ada beberapa penelitian yang telah dilakukan oleh peneliti terdahulu menggunakan model pembelajaran kooperatif tipe Jigsaw dan dapat meningkatan kualitas proses dan hasil belajar siswa. Oleh karena itu diindikasikan dapat meningkatkan kualitas proses dan hasil belajar berbicara. Penelitian Tindakan Kelas yang relevan dengan penelitian ini antara lain; Moh Amin dalam jurnal PTKnya yang berjudul "Upaya Meningkatkan Kemampuan Menemukan Unsur Intrinsik Cerpen Melalui Kooperatif Model Jigsaw pada Siswa Kelas IX I SMP Negeri 1 Karangrayung Kabupaten Grobogan Tahun Pembelajaran 2010/2011". Dalam jurnal tersebut diperoleh hasil bahwa ada peningkatan keterampilan siswa dalam menemukan unsur intrinsik cerpen pada kelas IX 1 SMP Negeri 1 Karangraung Kabupaten Grobogan Tahun Pembelajaran 2010/2011. Kenaikan tersebut cukup baik yaitu dari nilai 65 pada siklus 1 menjadi 83 pada siklus 2 atau mencapai 18\% setelah penerapan tindakan menggunakan model pembelajaran kooperatif tipe Jigsaw. Selain itu, menurut Moh Amin ada juga perubahan tingkah laku siswa dalam pembelajaran menemukan unsur intrinsik cerpen dengan menggunakan model kooperatif tipe Jigsaw tersebut. Penelitian lain yang relevan dilakukan oleh Safiruddin (2010). Dalam tesisnya berjudul "Peningkatan Prestasi Belajar Siswa Melalui Model Pembelajaran 
Kooperatif Tipe Jigsaw Pada Materi Fungsi Komposisi dan Inversi di Kelas IX SMA Negeri 1 Banda Aceh"

Dalam penelitian tersebut dijelaskan bahwa hasil penelitian pada siklus I dari 32 siswa dalam satu kelas ada 24 siswa yang dikategorikan tuntas belajar dengan perolehan nilai rata-rata 76,7 dan persentase keaktifan siswa dalam belajar mencapai 37,5\%. Hasil belajar siswa pada siklus II juga menunjukkan peningkatan. Terbukti secara klasikal yang tuntas belajar ada 25 siswa dengan nilai rata-rata 78,3 dan persentase keaktifan siswa dalam belajar mencapai 50\%. Hasil belajar siswa pada siklus III juga meningkat menjadi 27 dengan memperoleh nilai rata-rata 78,5 dan persentase siswa yang aktif berbicara dalam pembelajaran mencapai $75 \%$. Oleh karena itu, Safiruddin menyimpulkan bahwa terjadi peningkatan prestasi belajar siswa melalui model pembelajaran kooperatif tipe Jigsaw pada materi fungsi komposisi dan inversi di kelas XI SMA Negeri 1 Banda Aceh.

Selanjutnya Penelitian Tindakan Kelas yang dilakukan oleh Erman (2007). Dalam Penelitian Tindakan Kelas yang dilakukannya yang berjudul "Peningkatkan Kemampuan Siswa dalam Mendengarkan Cerita melalui Model Kerja Kelompok Tipe Jigsaw pada Siswa Kelas VI SDS Tugu Ibu Kota Depok Tahun Pembelajaran 2007/2008". Dalam penelitian tersebut disimpulkan bahwa hasil penelitian penerapan model kerja kelompok tipe Jigsaw dapat meningkatkan kemampuan siswa mendengarkan. Hal tersebut menurutnya terlihat bahwa setelah dilakukan penerapan tindakan dengan menggunakan model kerja kelompok tipe Jigsaw terjadi peningkatan keterampilan berpikir kritis ketika siswa ditugasi memberikan tanggapan terhadap jawaban-jawaban tugas yang disajikan oleh kelompok lain dalam kegiatan presentasi. Rata-rata kemampuan mendengarkan pada siklus kesatu adalah 57 dan siklus kedua adalah 100. Oleh karena itu peneliti menyimpulkan kemampuan siswa dalam mendengarkan cerita dapat meningkat jika diterapkan model kerjasama kelompok tipe Jigsaw.

\section{Pengertian Model Pembelajaran}

Model adalah pola (contoh, acuan, ragam) dari sesuatu yang dibuat atau dihasilkan. Sedangkan pembelajaran adalah proses; cara; perbuatan menjadikan orang atau makhluk hidup belajar (Depdiknas, 2002:751). Model adalah bentuk representasi akurat sebagai proses aktual yang memungkinkan sesorang atau sekelompok orang mencoba bertindak berdasarkan model itu (Suprijono, 2011:45). Oleh karena itu, model yang dimaksud dalam penelitian ini adalah pola, ragam atau acuan yang digunakan dalam pembelajaran.

Pembelajaran mengandung arti bahwa setiap kegiatan yang dirancang untuk membantu seseorang mempelajari suatu kemampuan dan atau nilai yang baru. Sedangkan dalam proses pembelajaran pada awalnya guru diminta untuk mengetahui kemampuan yang dimiliki oleh siswa meliputi kemampuan dasar, motivasinya, latar belakang akademisnya, latar belakang sosial ekonominya atau yang disebut karakteristik siswa tersebut.
Menurut Dimyati (2013:62) pembelajaran adalah kegiatan guru secara terprogram dalam desain instruksional untuk membuat siswa belajar secara aktif yang menekankan pada penyediaan sumber. Dengan demikian pembelajaran pada dasarnya merupakan upaya guru untuk membantu siswa melakukan kegiatan belajar. Tujuan pembelajaran adalah terwujudnya efisiensi dan efektivitas kegiatan belajar yang dilakukan siswa. Pihak-pihak yang terlibat dalam pembelajaran adalah guru dan siswa baik perorangan maupun kelompok yang berinteraksi antara satu dengan yang lainnya. Isi kegiatan pembelajarannya adalah materi belajar yang bersumber dari kurikulum sudah merupakan program pendidikan. Proses kegiatannya adalah langkah-langkah kegiatan pembelajaran yang dilalui oleh guru dan siswa dalam pembelajaran tersebut.

Menurut Isjoni (2008:30) model pembelajaran adalah kerangka konseptual yang melukiskan prosedur yang sistematis dalam mengorganisasikan pengalaman belajar untuk mencapai tujuan belajar tertentu dan berfungsi sebagai pedoman bagi perancang pembelajaran dan para pengajar dalam merencanakan aktivitas belajar-mengajar. (Saiful Sagala, 2010:15). Oleh karena itu model pembelajaran memberikan kerangka dan arah bagi guru untuk mengajar.

Merujuk pada pendapat tersebut penulis menyimpulkan bahwa model pembelajaran adalah sebagai suatu rencana mengajar yang memperlihatkan pola pembelajaran tertentu, dalam pola tersebut dapat terlihat kegiatan siswa dan guru dalam mewujudkan kondisi belajar yang menyebabkan terjadinya belajar pada siswa. Di dalam pola pembelajaran yang dimaksud terdapat rentetan atau tahapan kegiatan guru dan siswa dalam proses pembelajaran.

Berdasarkan hal tersebut maka yang paling penting diketahui oleh para guru adalah mempelajari, menguasai, dan menambah wawasan tentang model pembelajaran yang bervariasi karena dengan menguasai model-model pembelajaran guru akan merasakan adanya kemudahan pelaksanaan pembelajaran di kelas sehingga tujuan yang hendak dicapai dalam proses pembelajaran dapat tercapai dan tuntas sesuai yang diharapkan.

\section{Pembelajaran Kooperatif}

Sesuai yang telah dijelaskan bahwa pembelajaran adalah proses; cara, perbuatan menjadikan orang atau makhluk hidup belajar. Pembelajaran merupakan sesuatu yang dilakukan oleh siswa bukan dibuat oleh siswa. Oleh karena itu, jika siswa dapat melakukan sesuatu tentu mereka akan memahami apa yang dibuatnya. Untuk membantu pemahaman siswa dalam melakukan sesuatu itu maka diperlukan kerja sama dengan orang lain. Dalam pembelajan disebut kooperatif.

Dalam Kamus Besar Bahasa Indonesia (Depdiknas, 2002:593) dinyatakan kooperatif adalah bersifat kerja sama; bersedia membantu. Selanjutnya menurut Isjoni (2007:6) kooperatif adalah mengerjakan sesuatu secara bersama-sama dengan saling membantu satu sama lainnya sebagai satu tim. Silberman (2009:7) mengatakan bahwa pembelajaran kooperatif dapat didefinisikan sebagai kelompok kecil 
agar para pelajar dapat bekerja sama untuk memaksimalkan proses pembelajaran satu sama lain. Lebih lanjut Trianto (2007:41) menyatakan pembelajaran kooperatif muncul dari konsep bahwa siswa akan lebih mudah menemukan dan memahami konsep yang sulit jika mereka saling berdiskusi dengan temannya. Siswa secara rutin bekerja dalam kelompok untuk saling membantu memecahkan masalah-masalah yang kompleks. Jadi hakikat sosial dan penggunaan kelompok sejawat menjadi aspek utama dalam pembelajaran kooperatif. Di dalam kelas yang menggunakan pembelajaran kooperatif, siswa belajar bersama dalam kelompok-kelompok kecil yang terdiri 45 siswa yang sederajat tetapi heterogen.

Tujuan dibentuknya kelompok tersebut adalah untuk memberikan kesempatan kepada semua siswa agar dapat terlibat secara aktif dalam proses berpikir dan kegiatan belajar. Selama bekerja dalam kelompok tugas anggota kelompok adalah mencapai ketuntasan materi yang disajikan oleh guru dan saling membantu teman sekelompoknya untuk mencapai ketuntasan belajar tersebut. Belajar belum selesai jika salah satu anggota kelompok ada yang belum menguasai materi pembelajaran.

Lie (2002:65) mengatakan bahwa pembelajaran kooperatif adalah pembelajaran gotong-royong, yaitu sistem pembelajaran yang memberi kesempatan kepada siswa untuk bekerja sama dengan siswa lain dalam tugas-tugas yang terstruktur. Selanjutnya Isjoni (2007:43) menyatakan cooperative learning mengandung pengertian bahwa sikap siswa atau perilaku bersama harus membantu di antara sesama, dalam struktur kerjasama yang teratur dalam kelompoknya keberhasilan kerjanya sangat dipengaruhi oleh keterlibatan setiap anggota kelompok itu sendiri. Pembelajaran kooperatif dapat meningkatkan minat belajar siswa menuju belajar yang lebih baik, tolongmenolong dalam beberapa perilaku sosial. Pembelajaran kooperatif dapat dirumuskan sebagai kegiatan pembelajaran kelompok yang terarah, terpadu, efektif, efisien, ke arah mencari atau mengkaji sesuatu melalui proses kerja sama dan saling membantu (sharing) sehingga tercapai proses dan hasil belajar yang produktif. Oleh karena itu model pembelajaran kooperatif cocok diterapkan dalam pembelajaran terutama untuk meningkatkan keaktifan berbicara karena dalam kooperatif, siswa dituntut aktif dalam kelompok dan termotivasi berbicara.

Berdasarkan pendapat para ahli yang telah dipaparkan tersebut dapat disimpulkan bahwa pembelajaran kooperatif adalah belajar bersama-sama, saling membantu satu dengan yang lainnya dan memastikan bahwa setiap anggota kelompok akan dapat menyalesaikan tugas yang telah ditentukan serta dapat mencapai tujuan yang diharapkan. Pembelajaran kooperatif dapat meningkatkan cara belajar siswa menuju belajar yang lebih baik, efektif, efisien, dan menimbulkan sikap tolong-menolong dalam perilaku sosial. Tujuan penerapannya adalah agar siswa dapat belajar secara berkelompok dengan cara saling menghargai pendapat dan memberikan kesempatan kepada temannya untuk mengemukakan gagasan, pendapat, serta perasaannya.
Dengan melaksanakan model pembelajaran kooperatif memungkinkan siswa dapat meraih keberhasilan dalam belajar. Di samping itu juga bisa melatih siswa untuk memiliki keterampilan baik keterampilan berpikir maupun keterampilan sosial seperti keterampilan mengemukakan pendapat, menerima saran dari teman, bekerja sama, rasa setia kawan, dan mengurangi timbulnya perilaku yang tidak diinginkan dalam kehidupannya di kelas.

\section{Tipe Jigsaw}

Jigsaw berasal dari bahasa Inggris yang artinya dalam bahasa Indonesia adalah gergaji ukir. Ada juga yang menyebutnya dengan istilah puzzle yaitu sebuah teka-teki menyusun potongan-potongan gambar. Lie (2007:69) memaparkan bahwa teknik Jigsaw dapat digunakan dalam pembelajaran membaca, menulis, mendengarkan, ataupun berbicara. Dengan menggunakan teknik Jigsaw guru dapat membantu mengaktifkan siswa sehingga bahan ajar menjadi lebih bermakna. Kemudian siswa bekerja sama dengan siswa lain dalam suasana gotong-royong dan mempunyai banyak kesempatan untuk mengolah informasi dan meningkatkan ketrampilan berkomunikasi.

Silberman, (2009:168) menyatakan Jigsaw Learning (belajar jigsaw) merupakan teknik yang memiliki kesamaan dengan teknik "pertukaran dari kelompok ke kelompok". Dalam teknik ini setiap siswa mengajarkan sesuatu kepada temannya yang lain. Setiap siswa mempelajari sesuatu yang dikombinasikan dengan materi yang telah dipelajari oleh siswa lain. Siswa dikelompokkan menjadi sebuah perkumpulan pengetahuan yang memiliki keahlian dalam materi yang dipelajarinya.

Bedasarkan pendapat para ahli tersebut dapat disimpulkan bahwa pada hakikatnya pembelajaran tipe Jigsaw adalah tipe pembelajaran kooperatif yang terdiri atas 4-5 anggota dalam satu kelompok yang bertanggung jawab atas penguasaan bagian materi belajar dan mampu mengajarkan bagian tersebut kepada anggota kelompoknya. Selain itu tipe Jigsaw dapat dikatakan sebagai salah satu cara untuk mengaktifkan siswa dalam kegiatan pembelajaran dengan tujuan agar siswa dapat mengembangkan ilmu pengetahuan atau pengalaman belajarnya sehingga bahan pembelajaran lebih bermakna.

\section{Karakteristik Kooperatif Tipe Jigsaw}

Ciri model pembelajaran kooperatif tipe Jigsaw ini memiliki tahap-tahap dalam penyelengaraannya. Tahaptahap tersebut yaitu awalnya siswa dikelompokkan dalam bentuk kelompok-kelompok kecil. Keanggotaan kelompok seyogianya heterogen baik dari segi kemampuan siswa maupun karakteristik lainnya. Dengan demikian cara yang efektif untuk menjamin heterogenitas kelompok tersebut adalah guru membentuk kelompok-kelompok siswa. Jika siswa dibebaskan membentuk kelompok biasanya mereka akan memilih teman-teman yang disukainya saja.

Jumlah siswa dalam satu kelompok dibatasi. Menurut Slavin dalam Isjoni (2007:55) jumlah anggota kelompok yang paling tepat hanya 4-6 anggota. Dalam Jigsaw setiap anggota kelompok ditugaskan untuk 
mempelajari materi tertentu. Kemudian masing-masing perwakilan kelompok bertemu dengan anggota-anggota dari kelompok lain yang mempelajari materi yang sama. Selanjutnya materi tersebut didiskusikan dan memahami setiap masalah sehingga perwakilan anggota kelompok tersebut dapat menguasai materi yang dibahas. Setelah mereka memahami dan menguasai materi yang telah dibahas masing-masing anggota kelompok kembali ke dalam kelompok asal, di kelompok asal perwakilan anggota kelompok akan mengajarkan materi yang telah dibahas di kelompok ahli kepada teman sekelompoknya.

\section{Langkah-Langkah Pembelajaran Kooperatif Tipe Jigsaw}

Menurut versi Aronson dalam Trianto, (2007:57), pembelajaran kooperatif tipe Jigsaw memiliki langkahlangkah pembelajaran sebagai berikut :

1. Siswa dibagi atas beberapa kelompok (tiap kelompok beranggota 4-5 anggota tim) yang disebut kelompok asal.

2. Tiap anggota dalam tim diberi bagian materi atau sub topik yang berbeda.

3. Setiap anggota kelompok membaca dan memahami materi atau sub topik yang ditugaskan kepada mereka dan bertanggung jawab untuk mempelajarinya.

4. Anggota dari kelompok lain yang telah mempelajari materi atau sub topik yang sama bertemu dalam kelompok-kelompok atau membentuk kelompok baru yang disebut tim ahli untuk mendiskusikan materi atau sub topik yang mereka dapatkan.

5. Setelah selesai berdiskusi, setiap anggota kelompok ahli kembali ke kelompok asal dan bergantian mengajar teman-temannya. Anggota lain dalam kelompoknya mendengarkan dengan sungguhsungguh dan jika perlu anggota kelompok boleh memberikan tanggapan.

6. Secara bergantian masing-masing kelompok mempresentasikan hasil kerjanya dan kelompok lain memberikan tanggapan.

7. Guru memberikan penguatan.

\section{METODE PENELITIAN Jenis Penelitian}

Penelitian ini merupakan penelitian tindakan kelas yang dilaksanakan dengan penerapan model kooperatif tipe Jigsaw untuk meningkatkan kualitas pembelajaran berbicara siswa kelas VIIA SMP Negeri 14 Kota Jambi. Penelitian tindakan kelas ini adalah bentuk penelitian yang dilaksanakan secara langsung oleh guru dalam praktik pembelajaran. Peneliti mengadakan tindakan berdasarkan masalah-masalah yang ditemukan di lapangan yang harus segera diatasi. Tindakan dilakukan dengan perencanaan, pelaksanaan, observasi, analisis dan refleksi.

\section{Subjek Penelitian}

Subjek penelitian ini adalah siswa kelas VII A berjumlah 32 orang dengan komposisi 7 laki-laki dan 25 perempuan. Kelas ini dijadikan objek penelitian karena di SMP N 14 Kota Jambi ada tujuh kelas paralel yaitu kelas VIIA, VIIB, VIIC, VIID, VIIE, VIIF, VIIG, VIIH, dan VII i. Kemampuan akademik siswa secara keseluruhan sama maka untuk menetapkan kelas yang menjadi subjek penelitian dilakukan secara random.

\section{Tempat dan Waktu Penelitian}

Penelitian ini dilaksanakan di kelas VIIA SMP Negeri 14 Kota Jambi selama empat bulan yaitu dimulai dari bulan Januari sampai dengan bulan April 2016.

\section{Siklus Penelitian}

Penelitian ini direncanakan dua siklus setiap siklus tiga kali pertemuan dengan melakukan perencanaan, pelaksanaan, observasi, analisis dan refleksi. Namun jika penerapan tindakan belum berhasil maka pelaksanaan tindakan akan dilanjutkan siklus berikutnya.

\section{Sumber Data \\ Data Penelitian}

Data penelitian tindakan kelas ini berupa data proses pembelajaran dan hasil belajar serta keaktifan berbicara siswa kelas VIIA SMP N 14 Kota Jambi. Data proses pembelajaran berupa aktivitas yang dilakukan oleh guru dan siswa serta aspek-aspek yang mendukung pelaksanaan pembelajaran dengan menggunakan model pembelajaran kooperatif tipe Jigsaw. Data dikumpulkan berdasarkan hasil observasi, catatan lapangan, dan angket.

\section{Sumber Data}

Ada tiga sumber data yang digunakan dalam penelitian ini, yaitu sumber dari siswa, guru, dan teman sejawat sebagai observer

1. Data yang diperoleh dari siswa bertujuan untuk mendapatkan data tentang aktivitas siswa dalam proses pembelajaran dan hasil belajar siswa.

2. Data yang diperoleh dari guru dan teman sejawat atau observer digunakan untuk mengetahui tingkat keberhasilan implementasi model pembelajaran kooperatif tipe Jigsaw dan aktivitas siswa dalam proses pembelajaran.

Data yang dipeloleh dari pelaksanaan tindakan siklus I merupakan dasar pelaksaan siklus II, data hasil siklus II sebagai dasar menentukan pengambilan keputusan apakah penerapan tindakan berhasil atau tidak.

\section{Pelaksanaan Penelitian}

Sebelum penelitian dilaksanakan terlebih dahulu peneliti mempersiapkan materi pembelajaran, menyusun rencana pembelajaran yang akan dijadikan penerapan tindakan, mempersiapkan instrumen penelitian yang akan digunakan untuk mengumpulkan data berupa lembar observasi, catatan lapangan, dan angket. Dalam pelaksanaan persiapan peneliti dibantu oleh tiga teman sejawat sebagai observer. Ketiga observer tersebut adalah guru bahasa Indonesia yang mengajar di SMP N 14 Kota Jambi. Selain membantu melakukan persiapan penelitian mereka juga membantu peneliti dalam mengumpulkan data aktivitas yang dilakukan oleh guru dan siswa dalam pembelajaran dengan menggunakan instrumen penelitian yang telah dipersiapkan. 


\section{Teknik Pengumpulan Data}

Pengumpulan data penelitian dilakukan melalui tes dan nontes. Tes yang digunakan adalah tes buatan guru. Hasil tes tersebut dimaksudkan untuk mengukur keberhasilan siswa mencapai kompetensi setelah berlangsungnya proses pembelajaran yang dikelola oleh guru di kelas. Sedangkan data nontes digunakan untuk mengungkap bagaimana peningkatan keaktifan berbicara siswa mengungkapkan pendapat, menanggapi pendapat teman, mengajukan pertanyaan, dan menjawab pertanyaan teman/guru dalam diskusi pada proses pembelajaran.

Pengumpulan data dilakukan pada waktu pelaksanaan pra-tindakan, pelaksanaan tindakan siklus I, siklus II, dan siklus III. Data nontes pada penelitian ini merupakan hasil dari observasi/pengamatan, catatan lapangan, dan penyebaran angket tertutup. Data yang dikumpulkan melalui pengamatan adalah semua tindakan atau aktivitas siswa dan guru selama proses pembelajaran. Pengumpulan data menggunakan instrumen yang telah dipersiapkan. Observasi yang dilakukan terhadap aktivitas siswa adalah hal-hal yang berkaitan dengan aktivitas berbicara mengemukakan pendapat secara spontan, mengemukakan pendapat karena ditunjuk, menanggapi pendapat teman, mengajukan pertanyaan, dan menjawab pertanyaan teman/guru dalam proses pembelajaran yang dilakukan melalui model kooperatif tipe Jigsaw.

Pengamatan terhadap guru meliputi aktivitas penerapan langkah-langkah model pembelajaran tipe Jigsaw untuk meningkatkan keterampilan berbicara yang difokuskan terhadap mengemukakan pendapat baik secara spontan maupun karena ditunjuk, menanggapi pendapat teman, mengajukan pertanyaan, dan menjawab pertanyaan teman/guru dalam proses pembelajaran yang dilakukan oleh siswa. Sedangkan data yang dikumpukan melalui tes diperoleh dari hasil tes unjuk kerja siswa kemudian diukur sesuai dengan kriteria yang telah ditentukan dan penskorannya dimasukkan ke dalam tabel sehingga mudah diverifikasi.

\section{Instrumen Penelitian}

Instrumen yang digunakan dalam penelitian ini adalah instrumen nontes. Instrumen nontes yang digunakan adalah pedoman observasi, catatan lapangan, angket tertutup.

\section{Pedoman observasi}

Observasi adalah cara menghimpun data yang dilakukan dengan pengamatan dan pencatatan secara sistematis terhadap berbagai peristiwa yang terjadi dalam pembelajaran di kelas. Observasi dilakukan dalam penelitian ini guna untuk mengamati aktivitas yang dilakukan oleh siswa dan guru selama proses pembelajaran berlangsung dengan menggunakan model pembelajaran kooperatif tipe Jigsaw. Pedoman observasi yang digunakan dalam penelitian ini ada dua, yaitu lembar observasi siswa dan guru. Lembar observasi siswa digunakan untuk mengumpulkan data mengenai sikap dan perilaku siswa selama proses pembelajaran berlangsung sedangkan lembar observasi untuk guru digunakan untuk mengumpulkan data tentang aktivitas yang dilakukan oleh guru tentang penerapan model pembelajaran kooperatif tipe Jigsaw.

\section{Catatan Lapangan}

Catatan lapangan pada penelitian ini merupakan jurnal harian yang ditulis bebas untuk mencatatat semua perkembangan yang terjadi dalam proses pembelajaran selama pelaksanaan tindakan. Setiap kegiatan yang terjadi dalam pengamatan ditulis pada catatan lapangan dengan tujuan untuk memaksimalkan data.

Catatan lapangan digunakan untuk mencatat kesesuaian dan kesenjangan perencanaan dengan pelaksanaan tindakan. Pembuatan catatan lapangan bertujuan agar apa yang dilakukan dapat memperoleh informasi yang dapat dipertanggungjawabkan. Catatan lapangan berisi aspek pembelajaran di kelas, pengelolaan kelas, interaksi siswa dengan guru, interaksi siswa dengan siswa. Catatan lapangan juga digunakan untuk mengetahui kejadian-kejadian yang dilakukan siswa selama kegiatan proses pembelajaran berlangsung, termasuk keunggulan dan kelemahan tindakan.

\section{Angket}

Angket yang digunakan merupakan daftar pertanyaan yang memuat respon siswa terhadap pembelajaran keterampilan berbicara menggunakan model kooperatif tipe Jigsaw.

\section{Rubrik penilaian keaktifan siswa berbicara dalam pembelajaran}

Rubrik penilaian dalam penelitian ini digunakan sebagai pedoman penilaian dalam pembelajaran unjuk kerja berbicara. Oleh karena itu tes yang digunakan dalam penelitian ini adalah tes unjuk kerja (tes praktik) berbicara. Tes unjuk kerja dilakukan untuk mengukur kemampuan berbicara siswa. Pengumpulan data melalui unjuk kerja siswa dilakukan sesuai kompetensi dasar yang dibahas. Rubrik penilaian yang digunakan disesuaikan dengan indikator pencapaian kompetensi yang akan dicapai.

\section{Teknik Analisis Data}

Data yang sudah diperoleh akan dianalisis. Data hasil nontes dianalisis secara kualitatif sedangkan data hasil tes dianalisis secara kuantitatif. Teknik analisis data kualitatif digunakan untuk menganalisis data berupa proses pembelajaran. Sedangkan teknik analisis data kuantitatif digunakan untuk menganalisis data berupa angka. Data kuantitatif dalam penelitian ini adalah hasil penilaian keaktifan berbicara siswa.

\section{Teknik Analisis Data Kualitatif}

Teknik analisis data kualitatif digunakan untuk menganalisis data berupa kualitas proses pembelajaran berbicara. Data kualitas proses tersebut diperoleh dari hasil observasi, catatan lapangan, dan angket selama proses pembelajaran berlangsung di kelas. Analisis kualitatif dilakukan dengan tahap-tahap berikut.

1. Reduksi data. Reduksi data adalah merangkum, memilih hal-hal yang paling pokok, dan memfokuskan hal-hal yang penting.

2. Data display (penyajian data). Data display (penyajian data) yang dilakukan dalam penelitian ini adalah data yang diperoleh peneliti dan para observer melalui lembar observasi, catatan lapangan, dan angket. Data yang diperoleh diklasifikasikan 
berdasarkan aspek (pernyataan) yang dijadikan fokus analisis.

Data yang akan dianalisis adalah: (a) Keaktifan siswa mengemukakan pendapat secara spontan, (b) Keaktifan mengemukakan pendapat karena ditunjuk, (c) Keaktifan menanggapi pendapat teman, (d) Keaktifan mengajukan pertanyaan, (e) Keaktifan menjawab pertanyaan teman/guru.

Hasil analisis dibandingkan antara siklus I, siklus II, dan siklus III pada pelaksanaan refleksi. Dengan menganalisis tingkat keberhasilan implementasi tipe Jigsaw kemudian dikategorikan dalam klasifikasi sangat baik, baik, cukup, kurang, dan sangat kurang. Penghitungan hasil observasi aktivitas berbicara siswa tersebut dengan menggunakan rumus berikut :

\section{Jumlah frekuensi yang diperoleh x 100}

Jumlah frekuensi ideal

3. Tahap simpulan. Simpulan dibuat berdasarkan data yang telah dianalisis. Dari kesimpulan tersebut dapat diketahui apakah tujuan penelitian sudah tercapai atau belum.

\section{Teknik Analisis Data Kuantitatif}

Teknik analisis data kuantitatif digunakan untuk menganalisis data yang berupa angka. Data ini diperoleh dari hasil tes unjuk kerja yang dilakukan oleh siswa. Data yang diperoleh melalui tes akan dianalisis dengan cara:

Menentukan kriteria skor tiap-tiap aspek yang dinilai, (b) Menghitung skor komulatif seluruhan aspek, (c) Merekapitulasi skor yang diperoleh siswa, (d) Menghitung persentase perolehan siswa. Penghitungan hasil tes tersebut dengan menggunakan rumus berikut :

\section{Jumlah skor yang diperoleh $\times 100$}

Jumlah skor ideal/maksimum

\section{Indikator Keberhasilan}

Indikator keberhasilan yang dilihat dalam penelitian ini adalah keberhasilan yang dicapai oleh siswa dan guru. Guru merupakan fasilitator yang sangat berpengaruh terhadap keberhasilan siswa oleh karena itu indikator keberhasilan yang diharapkan sebagai berikut:

1. Kualitas proses pembelajaran meningkat ditandai siswa yang aktif berbicara dalam proses pembelajaran mencapai $75 \%$.

2. Kualitas hasil belajar siswa meningkat ditandai siswa yang tuntas dalam pembelajaran mencapai $85 \%$.

\section{HASIL DAN PEMBAHASAN}

\section{Proses Pembelajaran Berbicara Siklus I}

Hasil penelitian ini diperoleh dari tiga tahap proses pemberian tindakan yaitu siklus I, siklus II, dan siklus III. Sedangkan hasil belajar siswa diperoleh dari pemberian tes hasil evaluasi belajar pada prasiklus, siklus I, siklus II, dan siklus III setelah siswa melakukan proses pembelajaran dengan menggunakan model kooperatif tipe Jigsaw. Data hasil penelitian proses pembelajaran disajikan dalam bentuk deskripsi data kualitatif sedangkan data hasil pembelajaran berupa tes disajikan dalam bentuk data kuantitatif.
Keberhasilan yang diperoleh siswa dari hasil proses pembelajaran dinyatakan dalam kategori sangat baik, baik, cukup, kurang, sangat kurang. Sedangkan keberhasilan berdasarkan hasil belajar yang diperoleh dinyatakan tuntas atau tidak tuntas. Siswa yang dinyatakan memiliki nilai kategori sangat baik apabila rentang nilai yang diperoleh siswa antara 90 - 100, kategori baik apabila rentang nilai yang diperoleh antara 80 - 89, kategori cukup memperoleh nilai antara 70 79 , kategori kurang memperoleh nilai antara 60 - 69, dan kategori sangat kurang apabila rentang nilai antara 0 - 59. Sedangkan siswa yang dinyatakan tuntas apabila hasil evaluasi belajarnya telah mencapai Kriteria Ketuntasan Minimal yang telah ditentukan sedangkan siswa dinyatakan tidak tuntas jika nilai hasil evaluasi belajarnya belum mencapai kriteria ketuntasan minimal.

Untuk mengetahui frekuensi keaktifan siswa berbicara selama mengukuti proses pembelajaran peneliti menggunakan lembar observasi dengan menggunakan teli. Penghitungan persentase aktivitas berbicara siswa selama proses pembelajaran berlangsung adalah menghitung hasil teli yang diperoleh siswa dengan menggunakan rumus:

\section{Frekuensi perolehan keaktifan berbicara $\times 100$}

Frekuensi Ideal

Dalam pelaksanaan tindakan, peneliti diamati oleh tiga observer, yaitu teman sejawat di sekolah yang juga mengampu mata pelajaran Bahasa Indonesia. Para observer melakukan pengamatan terhadap proses pembelajaran yang dilakukan oleh peneliti dan aktivitas berbicara yang dilakukan oleh siswa dengan menggunakan lembar observasi yang telah disediakan. Setelah diterapkan model pembelajaran kooperatif tipe Jigsaw pada siklus pertama keaktifan berbicara siswa meningkat dari sebelumnya. Untuk memperbaiki kelemahan yang terjadi dan mempertahankan keberhasilan yang telah dicapai pada siklus pertama maka penerapan tindakan dilakukan pada siklus kedua.

Tindakan yang diberikan pada siklus kedua juga dapat meningkatkan keaktifan berbicara siswa dalam proses pembelajaran pada pertemuan pertama, kedua, dan pertemuan ketiga walaupun peningkatan itu masih belum mencapai keberhasilan yang diharapkan. Setelah diterapkan kembali perbaikan tindakan model kooperatif tipe Jigsaw pada siklus kedua persentase keaktifan berbicara siswa semakin meningkat pada setiap pertemuan. Peningkatan hasil pembelajaran pada siklus kedua belum sesuai dengan yang diharapkan oleh karena itu penerapan tindakan dilanjutkan pada siklus ketiga.

Pelaksanaan siklus ketiga sama dengan pelaksanaan siklus pertama dan siklus kedua yaitu data diperoleh berdasarkan hasil observasi yang dilakukan oleh peneliti dan para observer selama pelaksanaan tindakan pada siklus kedua. Peningkatan keaktifan berbicara siswa pada siklus ketiga ini menunjukkan kemajuan yang baik. Terbukti dari 32 jumlah siswa ada duapuluh empat siswa aktif mengemukakan pendapat secara spontan, duapuluh enam siswa aktif mengemukakan pendapat karena ditunjuk, duapuluh empat siswa aktif menanggapi pendapat teman, 
duapuluh lima siswa aktif mengajukan pertanyaan, dan duapuluh lima siswa aktif menjawab pertanyaan yang diajukan teman/guru. Suasana penerapan model kooperatif tipe Jigsaw tampak efektif untuk meningkatkan keaktifan berbicara siswa.

Setelah diterapkan kembali perbaikan tindakan model kooperatif tipe Jigsaw pada siklus ketiga dari pertemuan pertama, kedua, dan ketiga keaktifan berbicara siswa semakin meningkat. Berdasarkan peningkatan keberhasilan penerapan tindakan model kooperatif tipe Jigsaw pada setiap pertemuan selama siklus pertama, siklus kedua, dan siklus ketiga yang semakin baik hingga mencapai keberhasilan yang telah ditentukan maka pelaksanaan tindakan diakhiri pada siklus ketiga.

Keunggulan tindakan yang diberikan pada siklus ketiga dapat meningkatkan kualitas proses pembelajaran berbicara. Peningkatan kualitas proses pembelajaran tersebut dapat dibuktikan dari peningkatan jumlah siswa yang aktif berbicara pada pertemuan pertama, kedua, dan ketiga yang semakin baik. Hingga akhir siklus ketiga siswa yang aktif berbicara dalam pembelajaran berjumlah 25 siswa jika dipersentasekan mencapai 78,12\%. Persentase keberhasilan keaktifan berbicara siswa dalam pembelajaran pada siklus ketiga ini telah melampaui dari keberhasilan yang telah ditetapkan. Target keberhasilan yang ditetapkan hanya $75 \%$. Berdasarkan keberhasilan yang telah dicapai tersebut maka penerapan tindakan dengan menggunakan model kooperatif tipe Jigsaw dianggap efektif dan efisien oleh karena itu penerapan tindakan berakhir sampai pada siklus ketiga. Terjadinya peningkatan jumlah siswa yang aktif berbicara dalam pembelajaran juga dianggap telah mencapai kualitas proses pembelajaran berbicara siswa.

Penerapan model kooperatif tipe Jigsaw juga dapat meningkatkan hasil belajar siswa. Hasil evaluasi belajar siswa pada siklus I ini dari 32 siswa hanya 25 siswa $(78,13 \%)$ yang tuntas dalam materi pembelajaran sedangakan ketuntasan belajar siswa yang diharapkan adalah 85\% dengan Kriteria Ketuntasan Minimal 75. Nilai hasil belajar siswa yang belum mencapai Kriteria Ketuntasan Minimal (KKM) masih ada 7 (21,87\%).

Hasil belajar siswa pada siklus kedua ini mengalami peningkatan. Tebukti dari 32 jumlah siswa 27 $(84,38 \%)$ telah tuntas dengan Kriteria Ketuntasan Minimal (KKM) 75. Masih ada 5 (15,62\%) siswa yang belum tuntas dalam pembelajaran. Peningkatan keberhasilan penerapan tindakan model kooperatif tipe Jigsaw pada setiap pertemuan selama siklus pertama dan siklus kedua belum sesuai dengan yang diharapkan maka untuk memaksimalkan pelaksanaan tindakan peneliti melakukan siklus ketiga. Hasil evaluasi belajar siswa pada siklus ketiga ini juga meningkat. Terbukti dari 32 siswa ada 28 (87,5\%) telah tuntas dalam pembelajaran. Persentase ketuntasan belajar siswa secara klasikal pada siklus pertama hanya mencapai $78,13 \%$ meningkat menjadi $84,38 \%$ pada siklus kedua, dan menjadi $87,5 \%$ pada siklus ketiga. Persentase keberhasilan tersebut termasuk ke dalam kategori sangat baik. Namun sampai akhir siklus ketiga masih ada empat siswa yang belum tuntas dalam pembelajaran. Siswa yang belum tuntas dalam pembelajaran diberi perbaikan atau remedial. Keunggulan tidakan yang diberikan pada siklus ketiga dapat meningkatkan kualitas hasil belajar siswa. Ketuntasan pembelajaran mencapai $87,5 \%$ tersebut telah melampaui ketuntasan belajar secara klasikal dari yang telah ditentukan pada awal pembelajaran yaitu $85 \%$.

Berdasarkan persentase peningkatan kualitas hasil belajar siswa yang telah diperoleh pada siklus ketiga ini yang telah menunjukkan peningkatan yang baik hingga melampaui persentase yang telah ditentukan maka penerapan tindakan dengan menggunakan model kooperatif tipe Jigsaw tidak dilanjutkan lagi.

\section{SIMPULAN}

Berdasarkan hasil yang telah diperoleh dari penelitian tindakan kelas ini, dapat disimpulkan bahwa :

a. Model pembelajaran kooperatif tipe Jigsaw dapat meningkatkan proses pembelajaran dan kualitas hasil belajar dan keaktifan berbicara siswa kelas VIIA SMP Negeri 14 Kota Jambi Tahun Pembelajaran 2015/2016. Hal ini dapat dibuktikan peningkatan keaktifan siswa mengemukakan pendapat baik secara spontan maupun melalui ditunjuk, peningkatan keaktifan menanggapi pendapat temann, peningkatan mengajukan pertanyaan, dan peningkatan menjawab pertanyaan teman/guru pada saat proses pembelajaran berlangsung setiap pertemuan pada siklus siklus I, II, dan III. Siswa yang aktif berbicara dalam proses pembelajaran hingga akhir siklus ketiga ada 26 siswa.

b. Model pembelajaran kooperatif tipe Jigsaw juga dapat meningkatkan kualitas hasil belajar siswa kelas VIIA SMP Negeri 14 Kota Jambi. Hal ini terbukti dari persentase pencapaian ketuntasan hasil belajar siswa pada siklus I, II, dan III. Persentase kualitas hasil belajar siswa hingga akhir siklus ketiga mencapai $87,5 \%$. Persentase kualitas hasil belajar yang telah dicapai melampaui persentase hasil belajar yang telah ditentukan yaitu $85 \%$.

\section{DAFTAR PUSTAKA}

Arikunto, S. 2001. Dasar-Dasar Evaluasi Pendidikan. Jakarta: Bumi Aksara.

Amin, M. 2011. Panduan Praktis Penelitian Tndakan Kelas.Yogyakarta: Inspirasi.

Barkley, E.E; Cross, P.K; Major, H.C. 2012. Collaborative Learning Techniques. Bandung: Nusa Media.

Depdiknas. 2002. Kamus Besar Bahasa Indonesia Edisi Ketiga. Pusat Bahasa Jakarta: Balai Pustaka.

Depdiknas. 2003. Undang-Undang Republik Indonesia Nomor 20 tentang Sistem Pendidikan Nasional. Jakarta: Depdiknas.

Depdiknas. 2004. Materi Pelatihan Terintegrasi. Jakarta: Direktorat Jenderal Pendidikan Dasar dan Menengah.

Imam. 2004. Materi Pelatihan Terintegrasi Bahasa Indonesia Pengembangan Keterampilan Berbicara. Direktorat Jenderal Pendidikan Dasar dan Menengah Direktorat Pendidikan Lanjutan Pertama: Depdiknas. 
Isjoni. 2007. Cooperative Learning Efektifitas Pembelajaran Kelompok. Bandung: Alfabeta.

Lie, A. 2002. Cooverative Learning; Mempraktikkan Cooperative Learning di Ruang-Ruang Kelas. Jakarta: Grasindo.

Mulyasa, E. 2010. Penelitian Tindakan Kelas. Bandung: Rosda Karya.

Mudini;, Purba, S; Muchlisoh. 2012. Pembelajaran Berbicara. Kementerian Dikbud. Jakarta: Pusat Pengembangan dan Pemberdayaan Pendidik dan Tenaga Kependidikan Bahasa.

Nurwardani, P. 2010. Bahan Belajar Mandiri Program BERMUTU. Kemendiknas: Direktorat Jenderal Peningkatan Mutu Pendidikan dan Tenaga Kependidikan.

Nurgiantoro, B. 2011. Penilaian Pembelajaran Berbahasa Berbasis Kompetensi. Yogyakarta: BPFE.

Permendiknas. 2006. Permendiknas Nomor 22 tentang Standar Isi Direktorat Manajemen Pendidikan Dasar dan Menengah Atas. Jakarta:Depdiknas.

.Roestiyah. 2012. Strategi Belajar Mengajar. Jakarta: Bina Aksara.

Rizema, S. 2013. Desain Evaluasi Belajar Bebasis Kinerja. Jogjakarta. Diva Press.

Rizema, S. 2014. Desain Belajar Mengajar Kreatif Berbasis Sains. Jogjakarta. Diva Press.

Rusman. 2014. Model-Model Pembelajaran. Jakarta: Grafindo Persada.

Suryosubroto. 1997. Proses Belajar Mengajar Di Sekolah.Jakarta: Rineka Cipta.

Sugiyono.2007. Metode Penelitian Kuantitatif, Kualitatif dan $R \& D$. Bandung: Alfabeta

Slamet,Y. 2008. Dasar-Dasar Keterampilan Berbahasa Indonesia. Surakarta: Lembaga Pengembangan Pendidikan dan UNS Press.

Silberman. 2009. Aktive Learning 101 Strategi Pembelajaran Aktif. Yogyakarta: Pustaka Insan Madani.

Sumarna, dkk. 2010. Bahan Belajar Mandiri Model Pembelajaran Program BERMUTU. Kemendiknas: Direktorat Jenderal Peningkatan Mutu Pendidikan dan Tenaga Kependidikan

Suprijono, A. 2011. CooperativeLearning Teori \& Aplikasi Paikem.Yogyakarta: Pustaka Pelajar.

Sagala, S. 2013. Konsep dan Makna Pembelajaran. Bandung: Alfabeta.

Trianto. 2007. Model-Model Pembelajaran Inovatif Berorientasi Konstruktivistik. Jakarta: Prestasi Pustaka.

Tarigan, D. 1997. Buku Materi Pokok Kependidikan Keterampilan Berbahasa. Jakarta: UT Depdikbud.

Tarigan, G. 2013. Berbicara Sebagai Suatu Keterampilan Berbahasa. Bandung: Angkasa. 